\title{
RESEARCH
}

Open Access

\section{Effect of Didymosphenia geminata coverage on the phytobenthic community in an Andean basin of Chile}

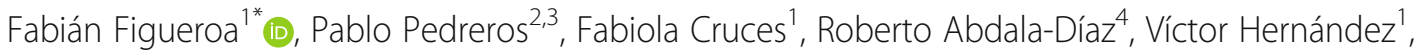
José Becerra ${ }^{1}$ and Roberto Urrutia ${ }^{2,3}$

\begin{abstract}
Background: The invasive diatom Didymosphenia geminata (Lyngbye) M. Schmidt has received considerable attention in recent years due to its rapid geographic expansion and massive proliferation, which have altered habitat availability for benthic species and triggered negative effects on stream ecosystems. We evaluated the changes in the community structure of phytobenthos caused by the temporal variation in D. geminata coverage, in addition to the environmental variables correlated with the temporal variation of this invasive microalga in the Andean sector of the Biobio River basin, Chile.

Methods: Environmental parameters were measured during the austral summer of 2014-2015, when phytobenthos samples were collected and used to develop a relative abundance matrix of taxa by calculating species richness and Shannon diversity. Multivariate techniques were used to establish the relationships among environmental variables, including D. geminata coverage, and the phytobenthic community.

Results: Massive proliferation of D. geminata occurs during summer (December-January). According to multiple regression analysis, electrical conductivity, temperature and total phosphorus were the variables that best explained the variation in D. geminata coverage. When D. geminata coverage was over $50 \%$, phytobenthic species richness was significantly higher than at the uninvaded site, without a significant change in Shannon diversity. In addition, the \% coverage of this invasive microalga and total phosphorus concentration were variables that differentiated phytobenthic communities among the study sites.

Conclusions: Environmental factors such as conductivity, temperature and total phosphorus concentration influenced the temporal variability of $D$. geminata mats. In addition, the massive growth of this invasive diatom caused a higher species richness without altering Shannon diversity. Our results suggest that the spatio-temporal variability of $D$. geminata correlated with environmental variables will help predict the habitat suitability of this alga in other Andean rivers and allow a better understanding of ecological habitat alterations.
\end{abstract}

Keywords: Rock snot, Freshwater microalga, Algal bloom, Stream habitat

\footnotetext{
*Correspondence: fafigueroa@udec.cl; fafigueroa.bm@gmail.com

'Department of Botany, Faculty of Natural and Oceanographic Sciences,

University of Concepcion, Concepción, Chile

Full list of author information is available at the end of the article
}

(C) The Author(s). 2018 Open Access This article is distributed under the terms of the Creative Commons Attribution 4.0 International License (http://creativecommons.org/licenses/by/4.0/), which permits unrestricted use, distribution, and reproduction in any medium, provided you give appropriate credit to the original author(s) and the source, provide a link to the Creative Commons license, and indicate if changes were made. The Creative Commons Public Domain Dedication waiver (http://creativecommons.org/publicdomain/zero/1.0/) applies to the data made available in this article, unless otherwise stated. 


\section{Background}

Invasive organisms are species that can settle outside of their natural distribution areas, triggering negative ecological and economic consequences [1]. During the last decade, the benthic diatom $D$. geminata (Lyngbye) $M$. Schmidt has been recognized as an invasive species that is capable of displacing benthic species [2, 3] given its significant proliferation and rapid dispersion in freshwater ecosystems [4]. This diatom has an apical pore through which it secretes a mucopolysaccharide stalk, allowing it to attach to various substrates [5], forming large macroscopic conglomerates that are resistant to bacterial degradation and may remain in the environment for weeks and months, even after cell death [6]. D. geminata is native to Europe, New Zealand and North America and inhabits lakes and rivers with low nutrient concentrations [7], although in recent decades it has been observed that it is expanding its geographical range, forming massive growths in rivers and lakes at high latitudes in South America [8-10].

Observations have shown that D. geminata has a high tolerance to changes in water quality [11-13] and its massive proliferation is mainly associated with low phosphorus concentrations [6,14-16], low current velocity and depth [17-19]. In addition, its ability to completely cover various riverbed substrates, make this benthic diatom not only a threat to other aquatic organisms, but also one of the most damaging invasive species in river ecosystems $[7,16,20,21]$, as it alters the availability of habitat for benthic species, causing changes in the food chain $[2,22]$. Much research in this area has focused on assessing the environmental variables that favor the settlement and proliferation of $D$. geminata $[15,19]$, but few studies have evaluated the effect of $D$. geminata mats on phytobenthic communities [23, 24].

In South America, studies on the proliferation of $D$. geminata have focused on taxonomic and phylogenetic aspects [5, 25] and the possibility of this microalga spreading to new water bodies $[8,9]$. Bhatt et al. (2008) suggested the need for studies focused on the monitoring of D. geminata population growth and possible interactions with other biotic communities. In this regard, changes to the taxonomic composition of phytobenthic communities can act as a roadmap to estimate the alteration of water bodies that have undergone ecological impacts [26]. Thus, communities, apart from providing more knowledge about microalgal flora [27], could also be considered an indicator of the impact of the massive proliferation of D. geminata.

The main objective of our study was to determine the effect of the variation in $D$. geminata coverage on the structure of phytobenthic communities. We also analyzed the environmental variables that correlate with the temporal variation of this invasive microalga in the Andean sector of the Biobio River basin, Chile.

\section{Materials and methods}

\section{Study area}

The Biobío River basin has a drainage area of $24,260 \mathrm{~km}^{2}$ and is considered a multiple-use river system (e.g., hydroelectricity generation, domestic and industrial effluent receiving, drinking water supply and fishing) [28]. Fieldwork was done between December 2014 and March 2015, in the austral summer. Sampling sites were selected in the main course of the Biobio River. Three of the analyzed sites were invaded by D. geminata (Marimenuco, MAR; Tallón, TAL; Lolén, LOL); a tributary free of Didymo blooms was included as non-invaded site (Liucura, LIU) (Fig. 1). The topographic composition of the study area results in highly variable and seasonal climate patterns, with cold-wet winters and hot-dry summers [29]. Average daily precipitation during the study period varied between 0 and $0.66 \mathrm{~mm}$, while average daily air temperature fluctuated between 7.11 and $20.63{ }^{\circ} \mathrm{C}$ (Dirección General de Aguas, DGA). The vegetation cover of this area consists of an Araucaria forest (Araucaria araucana, (Molina) K. Koch) with understory of Antarctic beech (Nothofagus antarctica, (G. Forster) Oerst). The species Festuca scabriuscula (Phil.), Acaena sericea (Phil.), Baccharis magellanica (Lam.) and Rumex acetosella (L.) dominate the herbaceous stratum $[29,30]$.

\section{River habitat characteristics}

At each study site, a section of approximately $50 \mathrm{~m}$ in length was selected considering the following criteria: similar substrate size, current velocity, depth and open canopy. Water quality variables were established with in situ measurements of temperature $\left({ }^{\circ} \mathrm{C}\right)$, conductivity $(\mu \mathrm{S} / \mathrm{cm}), \mathrm{pH}$ and dissolved oxygen $(\mathrm{mg} / \mathrm{L})$, using a Quanta multiparameter probe. Total nitrogen $(\mathrm{mg} / \mathrm{L})$, total phosphorus $(\mu \mathrm{g} / \mathrm{L})$ and soluble phosphorus $(\mu \mathrm{g} / \mathrm{L})$ were analyzed in the laboratory following APHA methodology [31]. Hydrological variables included flow velocity $(\mathrm{m} / \mathrm{s})$ and depth $(\mathrm{m})$, which were measured at substrate level using an FP111 Global Flow Probe. At each site, a total of six replicates for each variable measured in situ and three replicates for nutrients were considered. The River Habitat Index (IHF) described by Pardo et al. [32] was used to characterize the river habitat at each site. This index includes seven categories, which assess hydrogeomorphological aspects of the channel, including the presence and frequency of rapids, substrate composition, velocity and depth regimes, channel exposure, habitat heterogeneity and aquatic vegetation coverage.

\section{D. geminata coverage and phytobenthos sampling}

The presence of $D$. geminata was characterized according to the criteria described by [33], which are composed of five categories: Absent, no mucilaginous mats observed. Initial growth, less than $20 \%$ coverage, small brownish 


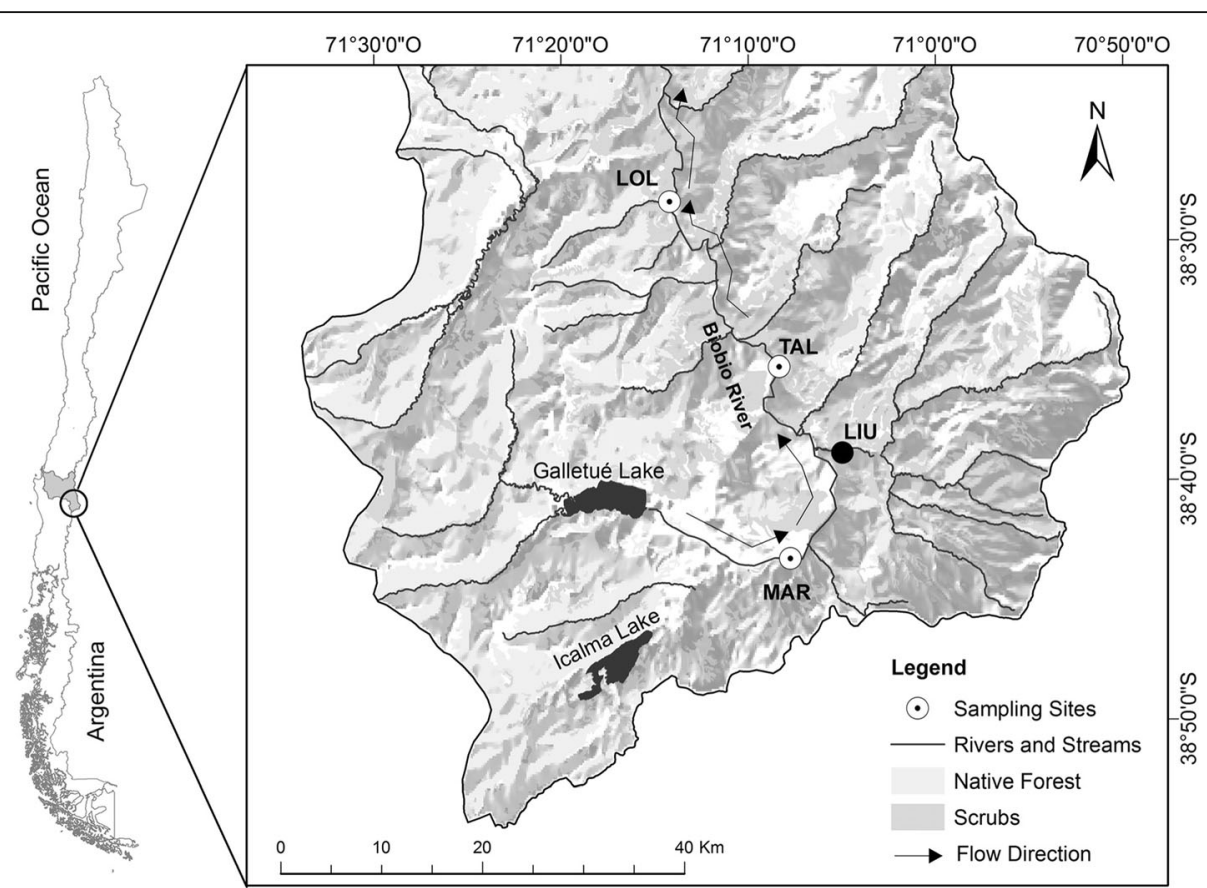

Fig. 1 Map of Andean section of the Biobio river basin (Chile). White circles indicate sites invaded by D. geminata and the black circle the site that was not invaded. The arrows indicate the flow direction

mats were observed. Medium growth, visual coverage $\geq 20 \%$ and no more than $50 \%$, some coalesced patches completely cover some rocks. High growth, coverage is $\geq 50 \%$ and less than $80 \%$, with the mats increasing in thickness and in dry conditions taking on the appearance of wet paper. Finally, growth was deemed massive when the thickness of the mats increased such that the bedrock and riparian vegetation were in large part covered (coverage $>80 \%$ ).

To determine $D$. geminata coverage at each invaded site, three similarly-sized submerged cobbles (greater than 12 $\mathrm{cm})$ were randomly chosen [33]. Then, a $16 \mathrm{~cm}^{2}$ area was defined using a plastic grid and photographed to determine the percent coverage using the IMAGE J program. This \% coverage of each cobble was included as an environmental variable in the data analysis.

Subsequently, epilithic samples were taken from the cobbles by scraping their upper surfaces on the aforementioned area and brushing and washing them in a plastic bowl until the selected area was completely clear. The collected material was deposited in 15 -mL plastic bottles and preserved in Lugol's solution at a temperature of $4 \pm 2{ }^{\circ} \mathrm{C}$ [25]. In the laboratory, samples were analyzed and up to 400 individuals were identified in each sample with a light microscope at a magnification of 1000 [34] using an Olympus CX31 equipped with a digital camera for microphotography. For specific diatom identification the samples were cleaned and mounted [35]. Taxonomic identification was carried out based on specialized literature
[36-40]. After counting the cells, a taxa abundance matrix was created, expressed in relative abundance (\%). In addition, the community parameters - species richness (number of species) and the Shannon diversity index for each site and month of sampling (between December 2014 and March 2015) - were calculated.

\section{Statistical analysis}

We used multiple linear regressions to identify environmental variables that best explained the temporal variability of D. geminata. Prior to this analysis, the independent variables that did not meet the assumptions of normality were transformed to $\ln (x+1)$. This analysis only considered sites invaded by $D$. geminata. A monthly comparison of the variables selected in the linear model, between the non-invaded site and each impacted site, was performed using nonparametric Mann-Whitney U comparisons. Differences in species richness and Shannon-Weaver diversity between the non-invaded and invaded sites were tested using nonparametric Mann-Whitney U comparisons. This analysis was conducted in R [41].

Principal coordinate analysis (PCoA) was performed to estimate similarity between the phytobenthos communities at different sampling sites. We used two-way permutational multivariate analysis of variance (PERMANOVA, [42]) to check whether there were differences in the phytobenthic community composition between the invaded and non-invaded sample sites and coverage categories. PCoA analysis methods were conducted using a Chord 
distance matrix [43] based on relative abundance of the phytobenthos community transformed to $\ln (x+1)$. In addition, a SIMPER analysis was performed to establish the similarity percentage in order to estimate the contribution of different phytobenthos species in the previously established groups (SIMPER, [44]). Finally, a distancebased linear model (DISTLM) was executed in order to determine the relationship between environmental variables and the phytobenthic community. Correlated environmental variables were eliminated from the analysis $(r>0.70)$. DISTLM analysis was carried out using forward selection under the Akaike information criterion (AIC) and coefficient of determination $\mathrm{R}^{2}$ to obtain a more detailed explanation of the behavior of the variables [45]. Significant differences were assumed when the $p$ value was $\leq 0.05$. PCoA, PERMANOVA and DISTLM analysis methods were performed with PRIMER 6.0 [46].

\section{Results}

River habitat characterization and environmental variables

D. geminata mats covered the majority of available substrates, particularly pebbles, stones, gravel, exposed roots, trunks and branches. Coverage of the invaded sites ranged between $<20 \%$ (initial growth) and $>80 \%$ (massive growth). The greatest $D$. geminata coverage was recorded at MAR during December-January, with values > $80 \%$ (massive growth). Conversely, the lowest coverage values were recorded at TAL, peaking at coverage $\geq 20 \%$ and no more than 50\% (medium growth) during December (Table 1).

The river habitat characterization of the non-invaded site presented IHF values that fluctuated between 74 and 81, indicating high habitat heterogeneity with low anthropogenic intervention and high colonization potential. Meanwhile, at the invaded sites IHF fluctuated between 58 and 69, indicating significant modifications in the stream habitat. The MAR, TAL and LOL sites presented lower values compared to LIU. The low values reported in the index are associated with a reduction in components of rapid frequency, velocity/depth regime and aquatic vegetation composition. The lowest IHF values were recorded during the months of greatest $D$. geminata coverage (December, January and February) (Table 1).

Multiple linear regression analysis suggested that conductivity, temperature and total phosphorus were the variables that best represented the variation in $D$. geminata coverage $\left(\mathrm{R}^{2}=0.80\right.$; adjusted $\left.\mathrm{R}^{2}=0.72 ; p<0.01\right)$. Throughout the study period, significant fluctuations in these variables between the invaded sites and non-invaded site were evident (Table 1). Conductivity presented lower values at MAR and higher values at downstream sites TAL and LOL. The temperature was higher at the invaded sites (MAR, TAL and LOL) than at the not-invaded site. In contrast, water depth presented minimal fluctuations, with no differences among the months. Finally, the three invaded sites presented lower total phosphorus concentrations compared to LIU. Paired comparisons between

Table 1 Mean values and standard deviation of the most significant environmental variables according to the multivariate linear model. Values of the River habitat index (IHF), D. geminata coverage, coverage categories described by Diaz et al. (2013) and the significant Mann-Whitney U test $\left(^{* * *}: p<0.001,{ }^{* *}: p<0.011^{*}: p<0.05\right.$; ns: non-significance)

\begin{tabular}{|c|c|c|c|c|c|c|c|c|c|c|c|}
\hline & Site & Month & Cond $\mu \mathrm{S} / \mathrm{cm}$ & $\begin{array}{l}\text { Sig-Dif } \\
(M-W)\end{array}$ & Temp C & $\begin{array}{l}\text { Sig-Dif } \\
(M-W)\end{array}$ & $\mathrm{TP} \mu \mathrm{g} / \mathrm{L}$ & $\begin{array}{l}\text { Sig-Dif } \\
(M-W)\end{array}$ & $\mathrm{IHF}$ & D. geminata \% & $\begin{array}{l}\text { Coverage } \\
\text { categories }\end{array}$ \\
\hline Non-invaded & LIU & Dec & $50.90 \pm 1.10$ & & $18.93 \pm 0.63$ & & $3.27 \pm 0.05$ & & 74 & 0 & \\
\hline \multirow[t]{3}{*}{ Invaded } & MAR & Dec & $49.35 \pm 0.55$ & $* *$ & $16.15 \pm 0.15$ & $* *$ & $2.68 \pm 0.04$ & $* * *$ & 60 & $91 \pm 4.47$ & Massive growth \\
\hline & $\mathrm{TAL}$ & Dec & $53.62 \pm 0.72$ & $* *$ & $13.33 \pm 0.08$ & $* *$ & $3.15 \pm 0.04$ & * & 64 & $48 \pm 3.96$ & Medium growth \\
\hline & LOL & Dec & $57.70 \pm 0.46$ & $* *$ & $17.37 \pm 0.20$ & $* *$ & $2.67 \pm 0.02$ & $* * *$ & 64 & $65 \pm 5.04$ & High growth \\
\hline Non- invaded & LIU & Jan & $52.70 \pm 2.00$ & & $21.45 \pm 0.78$ & & $5.15 \pm 0.03$ & & 79 & 0 & \\
\hline \multirow[t]{3}{*}{ Invaded } & MAR & Jan & $45.53 \pm 1.40$ & $* *$ & $20.75 \pm 0.49$ & * & $2.30 \pm 0.01$ & $* * *$ & 60 & $87 \pm 5.15$ & Massive growth \\
\hline & $\mathrm{TAL}$ & Jan & $52.78 \pm 0.44$ & * & $16.00 \pm 0.20$ & $* *$ & $1.66 \pm 0.04$ & $* * *$ & 61 & $29 \pm 5.42$ & Medium growth \\
\hline & LOL & Jan & $58.68 \pm 0.56$ & $* *$ & $18.63 \pm 0.21$ & $* *$ & $2.73 \pm 0.01$ & $* * *$ & 60 & $57 \pm 5.56$ & High growth \\
\hline Non-invaded & LIU & Feb & $55.20 \pm 1.20$ & & $15.42 \pm 2.30$ & & $4.76 \pm 0.03$ & & 77 & 0 & \\
\hline \multirow[t]{3}{*}{ Invaded } & MAR & Feb & $50.33 \pm 1.03$ & $* *$ & $14.48 \pm 0.21$ & $* *$ & $4.17 \pm 0.04$ & $* * *$ & 58 & $72 \pm 9.89$ & High growth \\
\hline & $\mathrm{TAL}$ & Feb & $59.33 \pm 0.82$ & $* *$ & $15.47 \pm 0.10$ & ns & $2.51 \pm 0.01$ & $* * *$ & 68 & $13 \pm 3.95$ & Absent \\
\hline & LOL & Feb & $65.50 \pm 2.43$ & $* *$ & $14.05 \pm 0.20$ & $* *$ & $4.37 \pm 0.01$ & $* * *$ & 63 & $27 \pm 7.88$ & Medium growth \\
\hline Non-invaded & LIU & Mar & $52.00 \pm 0.01$ & & $13.26 \pm 3.00$ & & $1.69 \pm 0.01$ & & 81 & 0 & \\
\hline \multirow[t]{3}{*}{ Invaded } & MAR & Mar & $48.50 \pm 1.38$ & $* *$ & $13.03 \pm 0.35$ & $* *$ & $1.63 \pm 0.04$ & Ns & 67 & $39 \pm 8.67$ & Medium growth \\
\hline & $\mathrm{TAL}$ & Mar & $54.67 \pm 0.52$ & $* *$ & $9.24 \pm 0.03$ & $* *$ & $1.35 \pm 0.02$ & $* * *$ & 72 & $4 \pm 3.37$ & Absent \\
\hline & LOL & Mar & $60.50 \pm 0.55$ & $* *$ & $9.89 \pm 0.03$ & $* *$ & $1.39 \pm 0.03$ & $* * *$ & 69 & $12 \pm 5.37$ & Absent \\
\hline
\end{tabular}


non-invaded and invaded sites during the study period showed that the major significant differences $(p<0.05)$ occurred in conductivity, temperature and total phosphorus (Table 1).

\section{Phytobenthos community}

A total of 51 taxa were observed in the phytobenthic community structure during the sampling period (December-March), the majority of which belong to the class Bacillarophyceae. When D. geminata coverage was greater than $50 \%$, the specific richness increased significantly with respect to the non-invaded site $(p<0.05)$, while when the coverage was less than $30 \%$, the richness was similar to that of the non-invaded site (Fig. 2). D. geminata was the taxon with the highest relative abundance at the MAR, TAL and LOL sites; however, it was observed that the abundance of the diatoms Rhopalodia gibba and Melosira varians present at the non-invaded site (LIU) also increased at the invaded sites. Meanwhile, the Shannon index showed no significant differences in species diversity between the non-invaded site and invaded sites.

The PCoA analysis based on the phytobenthos community differentiated the sites into two groups: one for the site that was not invaded by $D$. geminata (LIU) and the other for the invaded sites, explaining a total variation of 43.4\% (Fig. 3). A two-way PERMANOVA test presented a significant effect of the sites (Pseudo- $\mathrm{F}=3.29, p=0.0021$ ) and D. geminata coverage categories (Pseudo- $\mathrm{F}=2.46$, $p=0.004$ ) on the phytobenthos community. There was also significant interaction between both factors (Pseudo-F $=1.83, p=0.047$ ) (Table 2).

The relationship between environmental variables and the phytobenthos community determined by the DISTLM analysis demonstrated that under the Akaike criteria, $D$. geminata coverage (AIC $=56.33$; Pseudo- $\mathrm{F}=3.53$; $p=0.001)$ and total phosphorus $(\mathrm{AIC}=55.71$; Pseudo- $\mathrm{F}=2.32$; $p=0.013$ ) were the only variables included in the final model. Meanwhile, the coefficient of determination $\mathrm{R}^{2}$ included the total number of variables in the final model $\left(R^{2}=0.74\right)$; the only significant variables in the study site distribution were coverage $\left(R^{2}=0.20\right.$; Pseudo- $F=3.53$; $p=0.001)$ and total phosphorus $\left(\mathbb{R}^{2}=0.32\right.$; Pseudo- $\mathrm{F}=2.32$; $p=0.014)$. With both criteria, $D$. geminata coverage and total phosphorus concentration are variables that differentiate the phytobenthos communities among the sites.

The SIMPER analysis identified the species that contributed to differentiation between the non-invaded and invaded sites, with $81.17 \%$ dissimilarity between groups (Table 3). The top three dominant species at the invaded sites that most contributed to this dissimilarity percentage were Didymopshenia geminata (13.91\%), Aulacoseira granulata (Ehrenberg) Simonsen (4.99\%) and Rhopalodia gibba (3.66). At the non-invaded site (LIU) the species that most contributed to this dissimilarity were Fragilaria sp. (4.61\%), Cocconeis placentula Ehrenberg (4.52\%) and Gomphoneis minuta (Stone) Kociolek \& Stoermer (3.71\%). These results suggest that the change in species abundance was responsible for the high level of dissimilarity between sites.

The taxa that were positively related to the first dbRDA axis were those that were present at LIU, but absent or present at very low relative abundances at MAR, TAL and LOL. These include the species Gomphoneis minuta, Cymbella sp., Fragilaria sp., Cymbella affinis Kützing, Cocconeis placentula, Mougeotia sp. and Melosira hustedtii Krasske (Table 3, Fig. 4). Associated with massive $D$. geminata growth, an increase in relative abundance was observed for Rhopalodia gibba (Ehrenberg) Otto Müller, Melosira varians Agardh and Dolichospermum $s p$. Furthermore, Aulacoseira granulata, Fragilaria acus (Kützing) Lange-Bertalot and Scenedesmus quadricauda (Turpin) Brébisson were present only in invaded areas.

\section{Discussion}

In the last decade, massive proliferation of $D$. geminata has been observed in geographical areas where it had not been previously reported. This migration is probably due to human activity, which is the main vector for microalga propagation. However, [47] recently proposed that the expansion of the distribution range of D. geminata blooms is due to environmental changes. For example, the first cell registry of $D$. geminata in Chile dates back to the 1960s [48], although the first blooms in several rivers in southern Chile were reported 50 years later [49]. These observations show that D. geminata was not recently introduced to this region and that its cellular presence does not always cause massive blooms [50]. Thus, policies and management should focus on understanding the environmental factors that promote D. geminata blooms [47] and consider the variables related to the habitat window for the growth and persistence of $D$. geminata in river ecosystems. Our results indicate that the environmental parameters analyzed in this investigation showed little variability in the study period, in contrast to the great variability observed in $D$. geminata coverage. Thus, based on these results and in accordance with [17], the spatial variability in the coverage of $D$. geminata mats is explained by the habitat characteristics, and it is necessary to acquire data for long time series (annual, inter-annual) to highlight the importance of the environmental and hydrological variables that drive these changes. In our study, we emphasize that the application of the multivariate linear model indicated that conductivity, temperature and total phosphorus concentration were highly correlated with coverage of this microalga. Our results are consistent with previous studies $[15,51]$, which pointed out that 

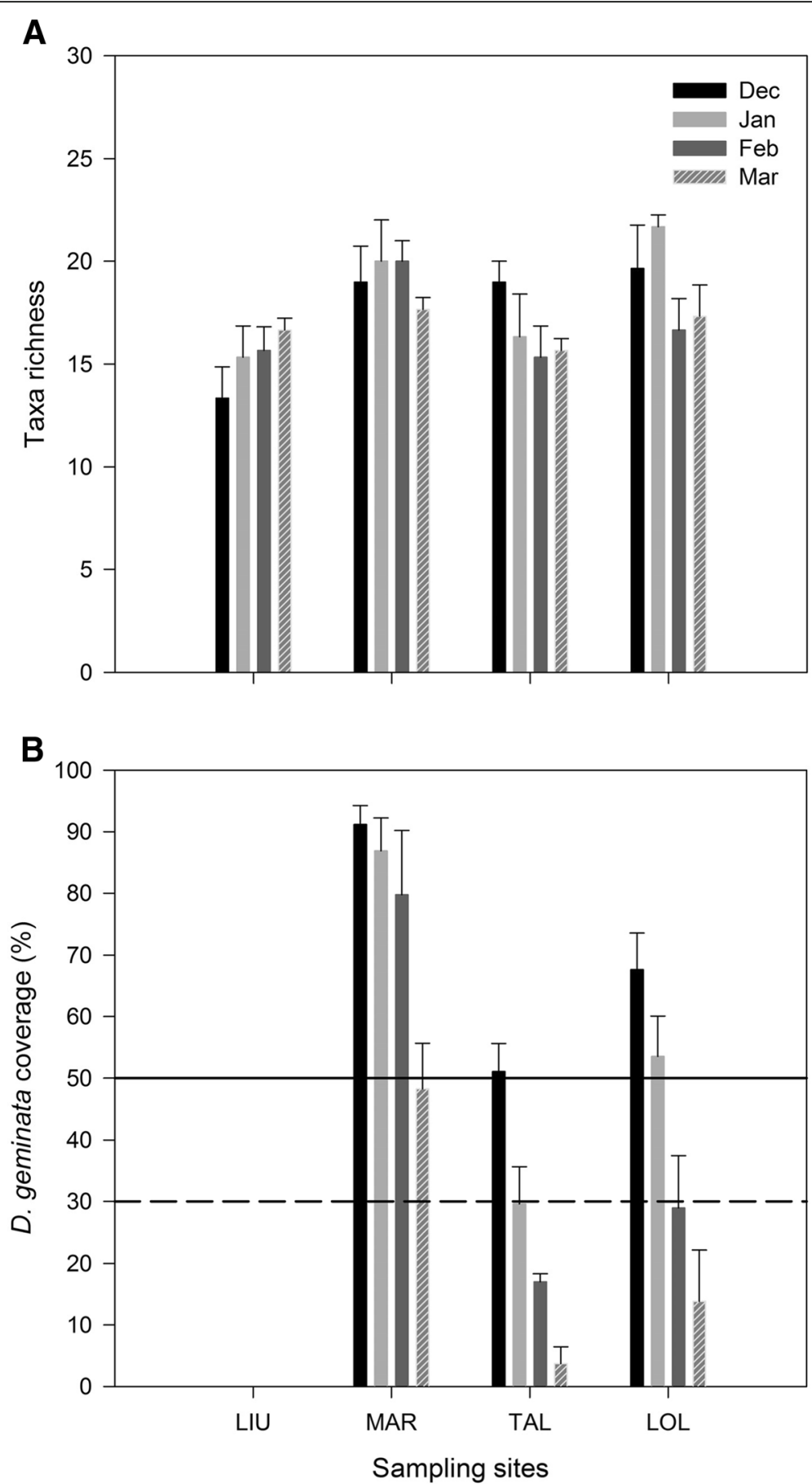

Fig. 2 a Richness of phytobenthic taxa at the different study sites. b D. geminata coverage (\%) at the different study sites. The dashed line indicates $30 \%$ D. geminata coverage and continuous line $50 \%$ coverage

such variables condition the establishment and temporal variation of $D$. geminata in rivers in Canada and the United States. Light availability was not measured in this study, but the reported low depths appeared to be directly related to light availability and the temperature in the water column, and, thus, to directly influence $D$. geminata growth. In this context, the combined effects of these factors (light-temperature) are determinants in the photosynthetic production of the invasive diatom $D$. geminata, favoring its success as a colonizer [52]. In the present work it was observed that during the months with the highest $D$. geminata coverage the 


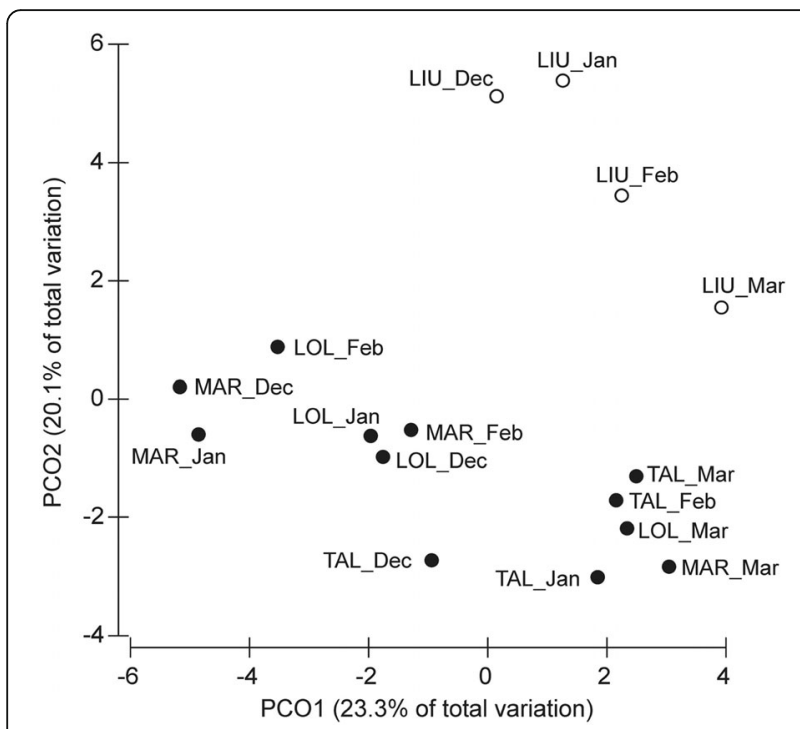

Fig. 3 Principal Coordinate Analysis ( $\mathrm{PCOA}$ ) based on relative abundance of the phytobenthos community for the studied months and sites ( white circle $=$ site not invaded by $D$. geminata; black circle $=$ sites invaded by $D$. geminata)

temperature was between 15 and $21^{\circ} \mathrm{C}$, which is similar to the range found in Spanish rivers [53].

Low concentrations of total phosphorus during the study period were related to the \% coverage of D. geminata mats. Similarly, [15] showed the existence of a negative relationship between the concentration of total phosphorus and D. geminata mat coverage. Low phosphorus concentrations promote cell division of this microalga and production of stalks that raise the cells above the substrate for better nutrient absorption, creating large mats that can remain in the environment for a long time [54, 55]. In contrast, during March at MAR an inverse relationship, with declining $D$. geminata coverage and increasing total phosphorus concentration, was observed, implying that other periphyton species have a competitive advantage over D. geminata [19]. Nonetheless, the low total phosphorus concentration recorded during March did not cause an increase in coverage. This was due to an increase in the flow rate as a result of the first rain of the month, causing $D$. geminata shedding.
Previous reports $[56,57]$ indicated that alterations in the flow regime are conditions for the establishment and continued presence of this invasive microalga. During the study period, the invaded sites had a decrease in the index compared to the non-invaded site (LIU) as a result of the decreasing values of the substrate composition and the velocity regime. Such physical alteration is associated with the ability of D. geminata to colonize all available benthic substrates [57].

The result of total substrate occupation by $D$. geminata generated a shift in phytobenthos community structure (Table 3, Fig. 4). A negative effect observed in this study was the decrease in relative abundance of the species G. minuta, C. affinis, and Cymbella sp. at the invaded sites (MAR, TAL, LOL) compared with the non-invaded site (LIU). This change could be attributed to the competitive pressure exerted by $D$. geminata on these phytobenthic species with similar ecological requirements, which were ultimately displaced by the massive proliferation of D. geminata $[16,58]$. Indeed, the total occupation of the substrate by this invasive microalga reduces the nutrient availability for the different strata of phytobenthos, which remain isolated after being covered by the filamentous mat formed by $D$. geminata. This is consistent with what was described by [59], who indicated that nutrient availability is lower at the base of the periphytic community than on its surface, implying that some species can monopolize space and other resources according to their level of morphological organization [60]. Similar conclusions were reached by [61], who suggested that the thickness of the periphytic layer affects nutrient availability, especially the lower layers, due to the speed of nutrient diffusion. In addition, the decrease in the abundance of G. minuta and Cymbella sp., dominant species in late successional stages, increases the availability of substrate, which makes a site more susceptible to the establishment of D. geminata [58]. Conversely, the presence of A. granulata, S. quadricauda, and $F$. acus only at sites invaded by $D$. geminata is due to the fact that these species come from Galletué Lake; when moving downstream, probably during periods of low river flow, they settle on the substrate, occupying the microhabitat formed by $D$. geminata stalks. Our results are similar to those reported by [16],

Table 2 Details of the two-way PERMANOVA test conducted on $\ln (x+1)$-transformed phytobenthos community abundance data recorded at the sampling sites

\begin{tabular}{llllccc}
\hline Source of variation & $\mathrm{df}$ & SS & MS & Pseudo-F & $p$ value & Unique perms \\
\cline { 2 - 7 } Sites & 3 & 174.36 & 58.12 & 3.29 & $\mathbf{0 . 0 2 1}$ & 997 \\
Coverage categories & 3 & 130.10 & 43.37 & 32.46 & $\mathbf{0 . 0 0 4}$ & $\mathbf{0 . 0 4 7}$ \\
Site x Coverage & 2 & 64.44 & 17.83 & & 998 \\
Res & 7 & 123.5 & & & \\
Total & 15 & 492.4 & & & & \\
\hline
\end{tabular}

Significant $p$-values are shown in bold 
Table 3 Similarity percentage analysis (SIMPER). Average abundance values are shown for phytobenthos species at sites non-invaded (LIU) and invaded (MAR, TAL, and LOL) by D. geminata. The comparison between both sites is shown, along with average dissimilarity values and contribution percentages (\%). Bacillariophyceae (B), Cyanophyta (C), Chlorophyta (Ch)

\begin{tabular}{|c|c|c|c|c|}
\hline \multirow[t]{2}{*}{ Species } & \multicolumn{2}{|c|}{ Average abundance } & \multirow{2}{*}{$\begin{array}{l}\text { Average } \\
\text { Dissimilarity }\end{array}$} & \multirow{2}{*}{$\begin{array}{l}\text { Contribution } \\
\%\end{array}$} \\
\hline & Non-invaded & Invaded & & \\
\hline Didymosphenia geminata (B) & 0.00 & 3.34 & 11.30 & 13.91 \\
\hline Aulacoseira granulata (B) & 0.00 & 1.50 & 4.05 & 4.99 \\
\hline Fragilaria sp. (B) & 2.33 & 0.70 & 3.74 & 4.61 \\
\hline Cocconeis placentula (B) & 1.90 & 0.61 & 3.67 & 4.52 \\
\hline Gomphoneis minuta (B) & 3.15 & 1.81 & 3.01 & 3.71 \\
\hline Rhopalodia gibba (B) & 2.17 & 3.22 & 2.97 & 3.66 \\
\hline Cymbella affinis (B) & 2.21 & 0.89 & 2.83 & 3.49 \\
\hline Cymbella sp. (B) & 2.52 & 1.26 & 2.64 & 3.26 \\
\hline Mougeotia sp. (Ch) & 1.59 & 0.94 & 2.51 & 3.09 \\
\hline Melosira varians (B) & 1.32 & 1.80 & 2.32 & 2.86 \\
\hline Fragilaria acus (B) & 0.00 & 1.10 & 2.27 & 2.80 \\
\hline Hannaea arcus (B) & 1.70 & 1.11 & 2.24 & 2.76 \\
\hline Melosira hustedtii (B) & 1.09 & 0.63 & 2.22 & 2.73 \\
\hline Dolichospermum sp. (C) & 0.85 & 1.85 & 2.22 & 2.73 \\
\hline Scenedesmus quadricauda (Ch) & 0.00 & 0.94 & 2.17 & 2.68 \\
\hline
\end{tabular}

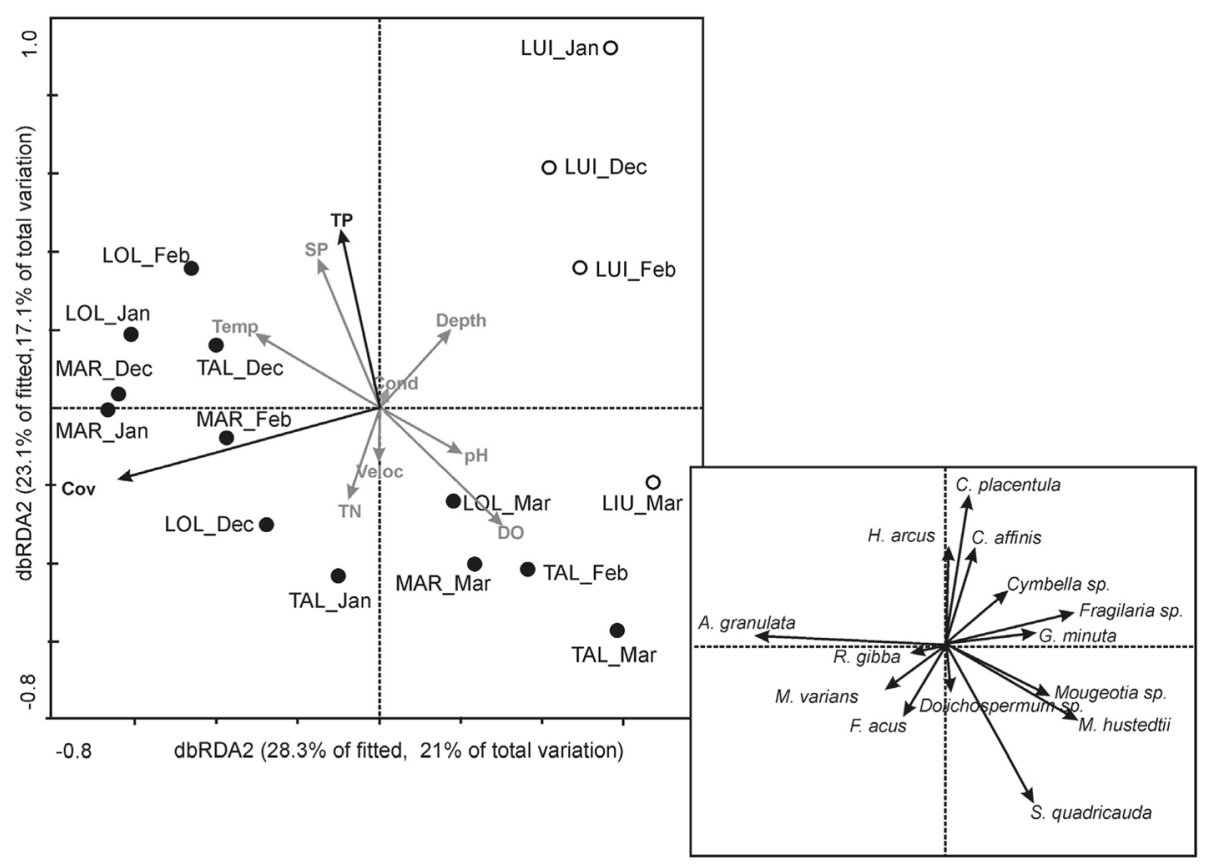

Fig. 4 Distance-based redundancy analysis of phytobenthos community and environmental variables. dbRDA analysis resulting from DISTLM for sampling sites (white circle $=$ site without $D$. geminata, black circle $=$ sites with $D$. geminata). The environmental variables shown are those determined by the coefficient of determination $\mathrm{R}^{2}$, with the most significant highlighted. The lower edge shows the taxa that contribute to $60 \%$ of the dissimilarity given by SIMPER between the sites that were invaded and not invaded by this microalga 
who described a positive relationship between the biomass of $D$. geminata and the relative abundance of other small diatoms. In addition, we observed the presence of a species of Chlorophyta after the growth of D. geminata, which is consistent with the findings of [53].

Although in this study no significant differences in species diversity were found (with respect to the non-invaded site), others have reported that the new microhabitats created by $D$. geminata filaments decrease or increase species diversity $[16,23,53]$.

Different studies have shown the effect of mats formed by $D$. geminata on the basis of the food web and higher trophic levels $[2,24]$, making it necessary to identify a threshold (\% of D. geminata coverage) that allows a determination of when the taxa change is generated. An interesting observation in this study is that richness is significantly higher when the coverage percentage of $D$. geminata is greater than $50 \%$. Subsequently, this richness decreases with the progressive reduction in the coverage of $D$. geminata, reaching values similar to those found at the non-invaded site. This alteration in the phytobenthic community was similar to that reported by [53], who found that the massive growth of $D$. geminata changes the taxonomic composition of phytobenthos, directly affecting its species richness.

\section{Conclusions}

We confirmed that conductivity, temperature and total phosphorus had a significant influence on variation in \% coverage of $D$. geminata. In addition, both the \% coverage of this invasive microalga and total phosphorus concentration were factors that influenced phytobenthos community structure, increasing phytobenthic species richness without altering taxa diversity. Meanwhile, a decrease in the abundance of other benthic diatoms at the invaded sites generated greater substrate availability, making them more susceptible to the establishment of D.geminata and resulting in an increase in the coverage of this invasive microalga. Nevertheless, the lack of studies regarding the presence of $D$. geminata in phytobenthic communities makes it difficult to understand the competition for available resources. Therefore, further studies that include competitive availability for resources, as well as ecophysiological and molecular aspects, should be carried out in order to better understand the interaction between this invasive microalga and other aquatic communities.

\section{Acknowledgements}

The authors are grateful for the support provided by CONICYT National Doctoral Scholarship N²1130577, sample identification support provided by Silvia Basualto and the observations made by Meyer Guevara-Mora, Fernando Torrejón and Denisse Álvarez.

\section{Funding}

This work was financially supported by CONICYT/FONDAP/ 15130015 project and CONICYT National Doctoral Scholarship N² 21130577.
Availability of data and materials

Not applicable.

\begin{abstract}
Authors' contributions
FF and PP: study design, field and laboratory work, data analysis, interpretation of results and manuscript drafting. FC: Interpretation of the phytobenthos results and manuscript review. RAD, VH, JB: study design, manuscript review. $\mathrm{RU}$ : study design, interpretation of the results of phytobenthos and manuscript review. All authors read and approved the final manuscript.
\end{abstract}

Ethics approval and consent to participate

Not applicable.

Consent for publication

Not applicable.

Competing interests

The authors declare that they have no competing interests.

\section{Publisher's Note}

Springer Nature remains neutral with regard to jurisdictional claims in published maps and institutional affiliations.

\section{Author details}

'Department of Botany, Faculty of Natural and Oceanographic Sciences, University of Concepcion, Concepción, Chile. ${ }^{2}$ Department of Aquatic Systems, Faculty of Environmental Sciences \& EULA-Chile Center, University of Concepcion, Concepción, Chile. ${ }^{3}$ Water Research Center for Agriculture and Mining (CHRIAM), University of Concepcion, Concepción, Chile.

${ }^{4}$ Department of Ecology, Faculty of Science, University of Malaga, Malaga, Spain.

Received: 15 June 2018 Accepted: 27 November 2018 Published online: 13 December 2018

\section{References}

1. Alpert P, Bone E, Holzapfel C. Invasiveness, invasibility and the role of environmental stress in the spread of non-native plants. Perspect Plant Ecol Syst. 2000;3:52-66.

2. Jellyman PG, Harding JS. Disentangling the stream community impacts of Didymosphenia geminata: how are higher trophic levels affected?. Biol Invasions. 2016;18:3419-35.

3. Larned S, Kilroy C. Effects of Didymosphenia geminata removal on river macroinvertebrate communities. J Freshw Ecol. 2014;29:345-62.

4. Coste M, Ector L. Diatomées invasives exotiques ou rares en France: Principales Observations effectuées au cours des dernières décennies. Syst Geogr Plants. 2000;70:373-400.

5. Rivera P, Basualto S, Cruces F. Acerca de la diatomea Didymosphenia geminata (Lyngbye) M. Schmidt: su morfología y distribución en Chile. Gayana Bot. 2013;70:373-400.

6. Whitton BA, Ellwood NTW, Kawecka B. Biology of the freshwater diatom Didymosphenia: a review. Hydrobiologia. 2009;630:1-37.

7. Blanco S, Ector L. Distribution, ecology and nuisance effects of the freshwater invasive diatom Didymosphenia geminata (Lyngbye) M. Schmidt: a literature review. Nova Hedwigia. 2009;88:347-422.

8. Montecino V, Molina X, Kumar S, Castillo ML, Bustamante R. Niche dynamics and potential geographic distribution of Didymosphenia geminata (Lyngbye) M. Schmidt, an invasive freshwater diatom in southern Chile. Aquat Invasions. 2014:9:507-19.

9. Reid BL, Hernández KL, Frangópulos M, Bauer G, Lorca M, Kilroy C, Spaulding S. The invasion of the freshwater diatom Didymosphenia geminata in Patagonia: prospects, strategies, and implications for biosecurity of invasive microorganisms in continental waters. Conserv Lett. 2012;5:432-40.

10. Sastre V, Santinelli N, Bauer G, Gabriela Ayestarán M, Uyua N. First record of the invasive diatom Didymosphenia geminata (Lyngbye) Schmidt in a Patagonian Andean river of Argentina. Bioinvasions Rec. 2013;2:11-7.

11. Kilroy CA. New alien diatom, Didymosphenia geminata (Lyngbye) Schmidt: its biology, distribution, effects and potential risks for New Zealand fresh waters. CHC: NIWA client report; 2004-128. p. 1-40.

12. Noga T, Stanek-Tarkowska J, Pajączek A, Peszek $Ł$, Kochman-Kędziora N. Expansion of Didymosphenia geminata (Lyngbe) M. Schmidt 
(Bacillariophyceae) in running waters in S-E Poland: new records in the podkarpacie region. J Environ Eng. 2014;15:31-9.

13. Spaulding S, Elwell L. Lncrease in nuisance blooms and geographic expansion of the freshwater diatom Didymosphenia geminata; U.S. Geological Survey Open-File Report; 2007-1425. p. 1-38.

14. Beamud S, Baffico G, Reid B, Torres R, Gonzalez Polo M, Pedrozo F, Diaz M. Photosynthetic performance associated with phosphorus availability in mats of Didymosphenia geminata (Bacillariophyceae) from Patagonia (Argentina and Chile). Phycologia. 2016;55:118-25.

15. Kirkwood AE, Shea T, Jackson $\amalg$, McCauley E. Didymosphenia geminata in two Alberta headwater rivers: an emerging invasive species that challenges conventional views on algal bloom development. Can J Fish Aquat Sci. 2007:64:1703-9.

16. Ladrera R, Gomà J, Prat N. Effects of Didymosphenia geminata massive growth on stream communities: smaller organisms and simplified food web structure. PLoS One. 2018;13:e0193545.

17. Gillis C-A, Dugdale SJ, Bergeron NE. Effect of discharge and habitat type on the occurrence and severity of Didymosphenia geminata mats in the Restigouche River, eastern Canada. Ecohydrology. 2018;11:e1959.

18. Giménez PT, Oscoz J, Durán C, Fernández Moreno D, Marín J. Distribution of the bloom-forming diatom Didymosphenia geminata in the Ebro River basin (north-East Spain) in the period 2006-2009. Aquat Invasions. 2010;5:285-9.

19. Miller MP, McKnight DM, Cullis JD, Greene A, Vietti K, Liptzin D. Factors controlling streambed coverage of Didymosphenia geminata in two regulated streams in the Colorado front range. Hydrobiologia. 2009;630:207-18.

20. George SD, Baldigo BP. Didymosphenia geminata in the upper Esopus Creek: current status, variability, and controlling factors. PLoS One. 2015;10:e0130558.

21. Kilroy C, Larned ST, Biggs BJF. The non-indigenous diatom Didymosphenia geminata alters benthic communities in New Zealand rivers. Freshw Biol. 2009;54:1990-2002.

22. Gillis C-A, Chalifour M. Changes in the macrobenthic community structure following the introduction of the invasive algae Didymosphenia geminata in the Matapedia River (Quebec, Canada). Hydrobiologia. 2010;647:63-70.

23. Gillis C-A, Lavoie I. A preliminary assessment of the effects of Didymosphenia geminata nuisance growths on the structure and diversity of diatom assemblages of the Restigouche River basin, Quebec, Canada. Diatom Res. 2014;29:281-92.

24. Sivarajah B, Kurek J, Rühland KM, Smol JP. Effects of Didymosphenia geminata blooms on benthic diatom assemblages in the Restigouche River watershed, eastern Canada. Botany. 2015;93:317-23.

25. Jaramillo A, Osman D, Caputo L, Cardenas L. Molecular evidence of a Didymosphenia geminata (Bacillariophyceae) invasion in Chilean freshwater systems. Harmful Algae. 2015;49:117-23.

26. Komulaynen $\mathrm{S}$. Use of phytoperiphyton to assess water quality in northwestern Russian rivers. J Appl Phycol. 2002;14:57-62.

27. Komulaynen $\mathrm{F}$. The structure and distribution of phytoperiphyton community in the Teno river and its tributaries (Finnish Lapland). Boreal Environ Res. 2008;13:517-24.

28. Parra O. El río Biobío: El Recurso Natural Base del Desarrollo de la Región. Concepción: Ediciones Universidad de Concepción; 1996.

29. Faranda F, Parra O. Evaluación de calidad de agua y ecología del sistema limnético y fluvial del Río Biobío: Ediciones Universidad de Concepción; 1993.

30. Luebert F, Pliscoff P. Sinopsis bioclimática y vegetacional de Chile. Santiago de Chile: Editorial Universitaria; 2006.

31. APHA. Standard methods for examination of water and wastewater. In: American public health association. 22th ed; 2012.

32. Pardo I, Alvarez M, Casas J, Moreno JL, Vivas S, Bonada N, Alba-Tercedor J, Jaimez-Cuéllar P, Moyá G, Prat N, Robles S, Suárez Alonso M, Toro M, VidalAbarca M. El hábitat de los ríos mediterráneos. Diseño de un índice de diversidad de hábitat. Limnetica. 2002;21:115-33.

33. Díaz C, Molina X, Montecino V. Manual para el Monitoreo e Identificación de la Microalga Bentónica Didymosphenia geminata. Subsecretaria de Pesca y Acuicultura. Chile: SUBPESCA; 2013. p. 1-105.

34. Bate N, Newall P. Techniques for the use of diatoms in water quality assessment: how many valves?. Diatom Symposium; 1998. p. 153-8.

35. Hasle G, Fryxell G. Diatoms: cleaning and mounting for light and Electron microscopy. Trans Am Microsc Soc. 1970;89:469-74.

36. Hofmann G, Lange-Bertalot H, Werum M. Diatomeen im Sübwasser-Benthos von Mitteleuropa. Königstein: Koeltz Scientific Books; 2013.

37. Parra O, González M, Dellarossa V, Rivera P, Orellana M. Manual taxonómico del fitoplancton de aguas continentales con especial referencia al fitoplancton de Chile. I: Cyanophyceae. Concepción, Editorial Universidad de Concepción; 1982.

38. Parra O, González M, Dellarossa V, Rivera P, Orellana M. Manual taxonómico del fitoplancton de aguas continentales con especial referencia al fitoplancton de Chile, III: Chyptophyceae, Dínophyceae y Euglenophyceae. Concepción, Editorial Universidad de Concepción; 1982.

39. Parra O, González M, Dellarossa V, Rivera P, Orellana M. Manual taxonómico del fitoplancton de aguas continentales: con especial referencia al fitoplancton de Chile. V: Chlorophyceae, Parte 1: Volvocales, Tetrasporales, Chlorococcales y Ulothricales. Concepción, Editorial Universidad de Concepción; 1982.

40. Rumrich $\mathrm{U}$, Lange-Bertalot $\mathrm{H}$, Rumrich M. Diatomeen der Anden: von Venezuela bis Patagonien/Feuerland : und zwei weitere Beiträge. A.R.G. Gantner Verlag K.G; 2000.

41. RC Team. R: a language and environment for statistical computing. Vienna: R Foundation for Statistical Computing; 2016.

42. Anderson MJ. A new method for non-parametric multivariate analysis of variance. Austral Ecol. 2001;26:32-46.

43. Orloci L. An agglomerative method for classification of plant communities. J Ecol. 1967;55:193-206

44. Clarke K, Gorley R. Primer v6: user manual/tutorial. Plymouth: Primer-E Ltd; 2006

45. Sokal RR, Rohlf FJ. The principles and practice of statistics in biological research. New York: WH Freeman and Company; 1981.

46. Anderson M, Gorley R, Clarke K. PERMANOVA + for PRIMER: Guide to Software and Statistical Methods; 2008. p. 1-214.

47. Taylor $\mathrm{B}$, Bothwell $\mathrm{M}$. The origin of invasive microorganisms matters for science and policy: the case of Didymosphenia geminata. Bioscience. 2014; 64:531-8.

48. Asprey J, Benson-Evans K, Furet J. Contribution to the study of South America freshwater phytoplancton. Gayana Bot. 1964;10:1-18.

49. Segura P. A slimy invader blooms in the Rivers of Patagonia. Science. 2011; 331:18.

50. Kilroy C, Novis PI. Didymosphenia geminata an introduced species in New Zealand? Evidence from trends in water chemistry and chloroplast DNA. Ecol Evol. 2018:8:904-19.

51. James DA, Mosel K, Chipps SR. The influence of light, stream gradient, and iron on Didymosphenia geminata bloom development in the Black Hills, South Dakota. Hydrobiologia. 2014;721:117-27.

52. El-Sabaawi R, Harrison PJ. Interactive effects of irradiance and temperature on the photosynthetic physiology of the pennate diatom Pseudo-nitzschia granii (Bacillariophyceae) from the northeast subarctic Pacific. J Phycol. 2006; 42:778-85.

53. Sanmiguel A, Blanco S, Álvarez-Blanco I, Cejudo-Figueiras C, Escudero A, Pérez ME, Noyón G, Bécares E. Recovery of the algae and macroinvertebrate benthic community after Didymosphenia geminata mass growths in Spanish rivers. Biol Invasions. 2016;18:1467-84.

54. Aboal M, Marco S, Chaves E, Mulero I, García-Ayala A. Ultrastructure and function of stalks of the diatom Didymosphenia geminata. Hydrobiologia. 2012;695:17-24

55. Bothwell ML, Taylor BW, Kilroy C. The Didymo story: the role of low dissolved phosphorus in the formation of Didymosphenia geminata blooms. Diatom Res. 2014;29:229-36.

56. Cullis J, Gillis C-A, Bothwell M, Kilroy C, Packman A, Hassan M. A conceptual model for the blooming behavior and persistence of the benthic matforming diatom Didymosphenia geminata in oligotrophic streams. J Geophys Res Biogeosci. 2012;117:G00N03.

57. Ladrera R, Prat N. Changes in macroinvertebrate community and biotic indices associated with streamflow regulation and wastewater inputs in sierra Cebollera Natural Park (La Rioja, northern Spain). Limnetica. 2013;32:353-72

58. Flöder S, Kilroy C. Didymosphenia geminata (Protista, Bacillariophyceae) invasion, resistance of native periphyton communities, and implications for dispersal and management. Biodivers Conserv. 2009;18:3809.

59. Stevenson R, Glover R. Effects of algal density and current on ion transport through periphyton communities. Limnol Oceanogr. 1993;38:1276-81.

60. Grime J. Plant strategies and vegetation processes. Chichester: Wiley; 1979.

61. Stelzer RS, Lamberti GA. Effects of N: P ratio and total nutrient concentration on stream periphyton community structure, biomass, and elemental composition. Limnol Oceanogr. 2001:46:356-67. 